\title{
7. GEOCHEMISTRY AND MINERALOGY OF SEDIMENTS, ATLANTIS II FRACTURE ZONE, SOUTHWEST INDIAN OCEAN ${ }^{1}$
}

\author{
Eileen Van der Flier-Keller ${ }^{2}$
}

\begin{abstract}
Thirteen sediment samples, including calcareous ooze, sandy clay, volcanic sand, gravel, and volcanic breccia, from Ocean Drilling Program (ODP) Sites 732B, 734B, 734G and Conrad Cruise 27-9, Station 17, were examined. Contents of major and trace elements were determined using XRF or ICP (on samples $<0.5 \mathrm{~g}$ ). Determinations of rare earth elements (REE) were performed using ICP-MS. Mineralogy was determined using XRD.

On the basis of the samples studied, the sediments accumulating in the Atlantis II Fracture Zone are characterized by generally high $\mathrm{MgO}, \mathrm{Cr}$, and $\mathrm{Ni}$ contents compared with other deep-sea sediments. A variety of sources are reflected in the mineralogy and geochemistry of these sediments. Serpentine, brucite, magnetite, and high $\mathrm{MgO}, \mathrm{Cr}$, and $\mathrm{Ni}$ contents indicate derivation from ultramafic basement. The occurrence of albite, analcime, primary mafic minerals, and smectite/chlorite in some samples, coupled with high $\mathrm{SiO}_{2}, \mathrm{Al}_{2} \mathrm{O}_{3}, \mathrm{TiO}_{2}, \mathrm{Fe}_{2} \mathrm{O}_{3}, \mathrm{~V}$, and $\mathrm{Y}$ indicate contribution from basaltic basement. A third major sediment source is characterized as biogenic material and is reflected primarily in the presence of carbonate minerals, and high $\mathrm{CaO}, \mathrm{Sr}, \mathrm{Pb}$, and $\mathrm{Zn}$ in certain samples. Kaolinite, illite, quartz, and some chlorite are most likely derived from continental areas or other parts of the ocean by long-distance sediment transport in surface or other ocean currents. Proportions of source materials in the sediments reflect the thickness of the sediment cover, slope of the seafloor, and the nature of and proximity to basement lithologies. REE values are low compared to other deep-sea sediments and indicate no evidence of hydrothermal activity in the Atlantis II Fracture Zone sediments. This is supported by major- and trace-element data.
\end{abstract}

\section{INTRODUCTION}

Fracture zones are ubiquitous features in all ocean basins; however, little is known regarding their sediment characteristics. Representative samples of major sediment types from the Atlantis II Fracture Zone were taken at ODP Sites 732B, 734B, 734G, and during Conrad Cruise 27-9, Station 17, to study the geochemical and mineralogical properties of sediments occurring in this tectonic setting. The purpose of this research is (1) to characterize the Atlantis II Fracture Zone sediments by mineralogy and compositions of major and trace elements, (2) to isolate characteristics that are unique to the fracture-zone environment by comparison with other parts of the Indian Ocean and elsewhere, (3) to determine sources and associations of components in the sediments, and (4) to examine the evidence for hydrothermal influences on the sediments using REE data.

The Atlantis II Fracture Zone is one of several major transform faults that offset the slow-spreading (approximately $0.8 \mathrm{~cm} / \mathrm{yr}$ [Fisher and Sclater, 1983]) Southwest Indian Ridge. The transform has an offset of approximately $210 \mathrm{~km}$, trends approximately north-south, and has substantial relief (on the order of $5800 \mathrm{~m}$ ). Although the walls of the valley are steep, typically $30^{\circ}$ to $40^{\circ}$, more subdued slopes exist locally. The sediment cover on the valley walls generally is thin (less than $10 \mathrm{~m}$ ), irregular, or nonexistent (Robinson, Von Herzen, et al., 1989). A median ridge bisects the valley and is covered with sediment and rubble of varying thickness. Two isolated sediment ponds were identified on the fracture-zone floor north of the transform (Conrad Cruise 27-9). Rubble composition is dominated by serpentinized peridotites, basalt, dia-

\footnotetext{
${ }^{1}$ Von Herzen, R. P., Robinson, P. T., et al., 1991. Proc. ODP, Sci. Results, 118: College Station, TX U.S.A. (Ocean Drilling Program).

${ }^{2}$ Department of Geography, University of Victoria, P.O. Box 1700, Victoria, British Columbia V8W 2Y2.
}

base, and subsidiary gabbro, greenstone, amphibolite, and sedimentary rock.

\section{SAMPLES}

Thirteen sediment samples (Table 1) from the Atlantis II Fracture Zone were examined. Samples were taken from Hole $732 \mathrm{~B}$ (Core 1 at $32^{\circ} 32.81^{\prime} \mathrm{S}, 57^{\circ} 03.289^{\prime} \mathrm{E}$ ), Hole $734 \mathrm{~B}$ (Core 1 at $32^{\circ} 06.82^{\prime} \mathrm{S}, 57^{\circ} 07.80^{\prime} \mathrm{E}$ ), Hole $734 \mathrm{G}$ (Core 3 at $32^{\circ} 06.87^{\prime} \mathrm{S}$, $57^{\circ} 08.24^{\prime} \mathrm{E}$ ) and from the Conrad Cruise 27-09, Station 17 (pilot Core 1 at $31^{\circ} 34.1^{\prime} \mathrm{S}, 57^{\circ} 08.4^{\prime} \mathrm{E}$ ). Site 732 is located on top of the median tectonic ridge, on a flat surface near the slope break and ridge crest. The ridge crest is covered by up to $5 \mathrm{~m}$ of soft sediment overlying sand and coarse bouldery gravel. Site 734 is on the east wall of the transform fault, on a steep $\left(25^{\circ}\right.$ to $\left.35^{\circ}\right)$, straight slope that exhibits no evidence of slumping or landsliding (Robinson, Von Herzen, et al., 1989, p.78). Sediment at this site consists of rubble, breccia, and sand overlain by foraminiferal ooze. Sediment sections $80 \mathrm{~cm}$ and 6 $\mathrm{m}$ long were recovered at Holes 734B and 734G, respectively. Station 17 of Conrad Cruise 27 is located in a sediment basin ( 4.5 to $5 \mathrm{~km}$ water depth and 10 to $20 \mathrm{~km}$ wide) on the east flank of the Atlantis II Fracture Zone. All samples analyzed in this study were retrieved from within $150 \mathrm{~cm}$ of the sediment surface, most commonly from the top $30 \mathrm{~cm}$ of the sediment column (Table 1). Sediment ages, on the basis of calcareous nannofossil biomarkers, are middle Pleistocene (Core 118732B-1H), Holocene (Core 118-734B-1H), and early Pleistocene (Core 118-734G-1H) (Robinson, Von Herzen, et al., 1989). The samples are representative of the range of sediment types encountered in this fracture zone and include calcareous (foraminiferal) ooze, sandy clay, volcanic sand (fine and coarse), gravel, and volcanic breccia.

\section{METHODS}

All samples were washed with distilled water prior to analysis. Eight samples were split into $<62 \mu \mathrm{m}$ and $>62 \mu \mathrm{m}$ size fractions. The mud was separated after freeze drying, 
Table 1. Location and lithology of sediment samples.

\begin{tabular}{|c|c|c|c|c|c|}
\hline \multirow[b]{2}{*}{ Sample } & \multirow{2}{*}{$\begin{array}{l}\text { Lithologic } \\
\text { description }\end{array}$} & \multirow[b]{2}{*}{ Core, section } & \multirow{2}{*}{$\begin{array}{c}\text { Interval } \\
\text { (cm) }\end{array}$} & \multicolumn{2}{|c|}{ Percentage } \\
\hline & & & & $>62 \mu \mathrm{m}$ & $<62 \mu \mathrm{m}$ \\
\hline AFZ4 & Volcanic sand & $118-732 \mathrm{~B}-1 \mathrm{H}$ & $18-24$ & & \\
\hline AFZ10 & Gravel and ooze & $118-732 B-1 H$ & $85-94$ & & \\
\hline AFZ5 & Sandy clay & $118-732 B-1 \mathrm{H}$ & $114-117$ & 28 & 72 \\
\hline AFZ11 & Gravel & $118-732 B-1 H$ & $142-146$ & & \\
\hline AFZ12 & Coarse sand & $118-732 \mathrm{~B}-1 \mathrm{H}$ & $146-150$ & & \\
\hline $\mathrm{AFZ1}$ & Foraminiferal ooze & $118-734 B-1 H$ & $3-4$ & 79 & 21 \\
\hline AFZ2 & Foraminiferal ooze & $118-734 \mathrm{~B}-1 \mathrm{H}$ & $13-15$ & 93 & 7 \\
\hline AFZ13 & Fine sand & $118-734 \mathrm{~B}-1 \mathrm{H}$ & $25-28$ & & \\
\hline AFZ6 & Calcareous ooze & $118-734 \mathrm{G}-3 \mathrm{H}$ & $1-2$ & 12 & 88 \\
\hline AFZ7 & Foraminiferal ooze & $118-734 \mathrm{G}-3 \mathrm{H}$ & $5-6$ & 89 & 11 \\
\hline AFZ3 & Volcanic breccia & $118-734 \mathrm{G}-3 \mathrm{H}$ & $16-17$ & 89 & 11 \\
\hline AFZ8 & Calcareous ooze & RC27-9 171 & $0-5$ & I & 99 \\
\hline AFZ9 & Calcareous ooze & $\mathrm{RC}_{27}-9171$ & 5 & 1 & 99 \\
\hline
\end{tabular}

washing, sonication for $60 \mathrm{~s}$, and wet sieving. The fines were centrifuged to remove salt, then freeze dried after washing. The sand was collected and dried at $80^{\circ} \mathrm{C}$. Weights of these fractions are listed in Table 1 . Where necessary, samples were crushed to -200 -mesh size using a tungsten carbide Blueller before splitting into separate fractions for geochemical and mineralogical analyses. Major and trace elements were analyzed by X-ray fluorescence (XRF). Because of the original small size of a number of the split samples, particularly from the finer-grained clay and ooze intervals, the final amount of material available for geochemical and mineralogical analyses was small. Where samples were smaller than $0.5 \mathrm{~g}$ (minimum sample size for XRF), major and trace elements were analyzed by inductively coupled plasma spectroscopy (ICP) following total digestion (samples AFZ 1, 2, 3, 7, 5S, and 6S). REE abundances were determined for these samples using ICP-mass spectrometry (MS). Precision of XRF analyses on the basis of duplicate measurements range from $0 \%$ to $7 \%$ for major elements, except for sodium $\left(\mathrm{Na}_{2} \mathrm{O}\right)$, which was $65 \%$.
Precision of trace-element values ranges from $2 \%$ to $14 \%$, except for cobalt $(\mathrm{Co})$, chromium $(\mathrm{Cr})$, vanadium $(\mathrm{V})$, and yttrium (Y), which was $43 \%$ to $59 \%$. Co and $\mathrm{Cr}$ levels are significantly lower in the duplicate samples than in the majority of other samples. Mineralogy was determined using X-ray diffraction (XRD). Scans were run on whole-round samples, or where insufficient sample was available, on either the $<62$ or $>62 \mu \mathrm{m}$ fractions. In addition, $<2 \mu \mathrm{m}$ fractions of samples AFZ8 and AFZ9 were separated and analyzed specifically for identification of clay minerals, i.e., untreated, following glycolation, and following heating to $375^{\circ}$ and $550^{\circ} \mathrm{C}$, respectively.

\section{RESULTS AND DISCUSSION}

\section{Mineralogy}

Qualitative mineral contents of the samples (or sample splits, as indicated) are given in Table 2. A wide range of igneous, metamorphic, and sedimentary minerals is present,

Table 2. Mineralogy of sediment samples, Atlantis II Fracture Zone.

\begin{tabular}{|c|c|c|c|c|c|c|c|c|c|c|c|c|}
\hline Sample & $\mathrm{Se}$ & Ch & $\mathrm{Sm}$ & $\mathrm{Ca}$ & $\mathrm{Ar}$ & Qt & Al & $\operatorname{Tr}$ & En & $\mathrm{Di}$ & An & \\
\hline $\mathrm{AFZ4}$ & $X X$ & $x$ & $x$ & & & & $X X X$ & $x X$ & $x$ & $X X$ & $X X$ & \\
\hline AFZ10 & $\mathrm{XX}$ & $\mathrm{x}$ & $x x$ & & & & $X X X$ & $X X X$ & $x$ & $X X$ & $x X$ & \\
\hline${ }^{a}$ AFZ5 & $\mathrm{X}$ & & & $X X X$ & & $X X X$ & $X X$ & & & & & \\
\hline AFZ11 & $\mathrm{X}$ & & $x$ & & & & $x x x$ & $X X$ & $X X$ & $X X X$ & $X X$ & \\
\hline AFZ12 & $X X X$ & & & & & & $X X X$ & $X X$ & $x$ & $x X$ & $X X X$ & $\mathrm{XBr}$ \\
\hline $\mathrm{b}_{\mathrm{AFZ1}}$ & $\mathrm{XX}$ & & & $X X X$ & $x X$ & & & & & & & $\mathrm{XMg}$ \\
\hline bAFZ2 & $\mathrm{XXX}$ & $\mathrm{X}$ & & $X X$ & $\mathrm{XXX}$ & $\mathrm{x}$ & & $x X$ & $\mathrm{XXX}$ & & & $\begin{array}{l}\mathrm{XBr} \\
\mathrm{XXMg} \\
\text { XII }\end{array}$ \\
\hline AFZ13 & $\mathrm{XXX}$ & & & & $\mathrm{XxX}$ & & & $\mathrm{x}$ & & & & $\begin{array}{l}\text { XBr } \\
\text { XXMg }\end{array}$ \\
\hline${ }^{\mathrm{a} A F Z 6}$ & $\mathrm{XX}$ & $\mathrm{X}$ & & $\mathrm{XXX}$ & & & & $\mathrm{X}$ & & & & $\begin{array}{l}\mathrm{XMg} \\
\mathrm{XBa}\end{array}$ \\
\hline${ }^{\mathrm{b}} \mathrm{AFZ7}$ & $X X X$ & $\mathrm{X}$ & & $X X X$ & $x X$ & & & $X X$ & $X X$ & & & $\mathrm{XBr}$ \\
\hline${ }^{b}{ }_{A F Z 3}$ & XXX & $\mathrm{X}$ & & $X X X$ & $\mathrm{XX}$ & & & $X X$ & $X X$ & & & \\
\hline${ }^{\mathrm{a}} \mathrm{AFZ8}$ & & & & $X X X$ & & $X X$ & $x$ & & & & & \\
\hline${ }^{\mathrm{a}} \mathrm{AFZ9}$ & & & & $X X X$ & & $x X$ & $x$ & & & & & \\
\hline \multicolumn{2}{|c|}{ AFZ $8<2 \mu \mathrm{m}$} & & $\mathrm{x}$ & & & $\mathrm{xX}$ & & & & & & $\begin{array}{l}\text { XKa } \\
\text { XII }\end{array}$ \\
\hline AFZ9 & & & $x$ & & & $X X$ & & & & & & $\begin{array}{l}\text { XKa } \\
\text { XII }\end{array}$ \\
\hline
\end{tabular}

a $<62 \mu \mathrm{m}$ fraction.

b $>62 \mu \mathrm{m}$ fraction.

$\mathrm{XXX}=$ abundant, $\mathrm{XX}=$ common, $\mathrm{X}=$ trace.

$\mathrm{Se}=$ Serpentine $; \mathrm{Al}=$ Albite $\mathrm{Mg}=$ Magnetite $; \mathrm{Ch}=$ Chlorite $\mathrm{Tr}=$ Hornblende; $\mathrm{Il}=\mathrm{Illite} ; \mathrm{Sm}=\mathrm{Smectite} / \mathrm{Ch}$

$\mathrm{En}=$ Enstatite $; \mathrm{Ba}=\mathrm{Barite} \mathrm{Ca}=\mathrm{Calcite} ; \mathrm{Di}=\mathrm{Diopside} /$ Augite $; \mathrm{Ar}=$ Aragonite $\mathrm{An}=$ Analcime $; \mathrm{Ka}=\mathrm{Kaolinite}$;

$\mathrm{Q} \mathrm{t}=$ Quartz; $\mathrm{Br}=$ Brucite. 
reflecting the contribution from a variety of sources. Smectite and chlorite are the most common clay minerals; however, traces of illite and kaolinite were determined in samples AFZ 8 and AFZ 9 ( $<2 \mu \mathrm{m}$ fractions). The latter was identified by the presence of an XRD peak at approximately $10 \AA$, and a broad peak at $7.15 \AA$, which became asymmetrical on glycolation, then disappeared when heated to $550^{\circ} \mathrm{C}$ and is thought to correspond to the presence of poorly crystallized or partially disordered kaolinite. Mixed-layer smectite-chlorite was identified as a broad peak from 12 to $15 \AA$, which expanded slightly upward on glycolation and collapsed to 10 $\AA$ when heated (Samples AFZ 8 and AFZ9). Peaks attributed to chlorite occurred at 7.15 and $3.52 \AA$.

Samples from Hole 732B typically contain plagioclase (albite), amphibole (tremolite or hornblende), clinopyroxene (diopside and/or augite), orthopyroxene (enstatite), serpentine (lizardite and chrysotile), analcime, and commonly smectite/ chlorite and chlorite. By contrast, samples from Holes 734B and $734 \mathrm{G}$ contain mainly serpentine, calcite, aragonite, amphibole, orthopyroxene, and chlorite in both the $<62$ and $>62$ $\mu \mathrm{m}$ fractions. Trace quantities of brucite and magnetite are also common in these samples. The most restricted mineralogy (calcite and quartz, with traces of smectite/chlorite, plagioclase, kaolinite, and illite) occurs in the Conrad 27-9 ooze samples. Vertical changes in mineralogy within any one core may be related primarily to lithology and the size fraction of the sample examined. However, in Hole 732B, similar lithologies show stratigraphic variations in mineralogy. Chlorite and smectite abundances decrease with depth, while serpentine is most abundant in the deepest sample.

Sources of the minerals noted in the fracture-zone sediments include (1) the immediate basement, (2) biogenic components, and (3) long-distance sediment transport from continental areas and other parts of the ocean.

1. Weathered, altered, and eroded basalt, diabase, and lesser peridotite are the likely primary source rocks at Hole $732 \mathrm{~B}$, while serpentinized peridotite may be the dominant source for sediments at Holes 734B and 734G. Minerals directly contributed from this source include primary igneous minerals, in addition to in-situ hydrothermal weathering products, such as serpentine, brucite, and magnetite (peridotite assemblage) and smectite-chlorite, albite, and analcime (basalt assemblage). On the basis of mineralogy, the ultramafic component is most important in sediments from Holes 734B and $734 \mathrm{G}$, while minerals present in sediments from Hole 732B are mainly derived from basaltic material.

2. Foraminiferal tests are thought to constitute the main source for the carbonate minerals. Water depths at Holes 732B, 734B, 734G, and Conrad 27-9 are 4878.3, 3670.4, 3417.4 , and 4500 to $5000 \mathrm{~m}$, respectively (Robinson, Von Herzen, et al., 1989). Local carbonate compensation depth (CCD) has been estimated as $4800 \mathrm{~m}$ in this latitudinal zone (Kolla et al., 1976). Some dissolution of nannofossil calcite thus may have occurred in sediments from Cores 118732B-1H and Conrad 27-9. Minor amounts of calcite may also be derived from altered igneous fragments.

3. High levels of kaolinite and quartz were found in the Madagascar Basin compared with other parts of the western Indian Ocean (Venkatarathnam et al., 1976; Venkatarathnam and Biscaye, 1977). Madagascar has been proposed as a likely source area for these minerals. It is probable that the kaolinite and quartz present in the Atlantis II Fracture Zone sediments also derived from Madagascar, possibly by surface or other ocean currents. Chlorite and illite contents are high in the southern part of the southwest Indian Ocean-Antarctic region (Venkatarathnam et al., 1976). The presence of these minerals in the Atlantis II Fracture Zone may indicate derivation from the Antarctic region (Rateev et al., 1969) via the Antarctic bottom-water current (AABW). Some smectite may have derived from the Crozier Basin to the east and south by the AABW; however, it most likely was locally formed. Basement and biogenous sources appear to be volumetrically the most important contributers to the fracture-zone sediments, especially as the circulation within the fault and access to major ocean currents would be expected to be low, given the elevated topography, rugged steep slopes, and localized flow of the AABW through the Southwest Indian Ridge (Warren, 1978). Where the sediment cover is thin, the basement source may be most important, while in sediment ponds (such as that from which Samples AFZ8 and AFZ9 were taken), the biogenous and long-distance contributions are higher.

\section{Geochemistry}

Results of geochemical analyses are listed in Table 3. Contents of major and trace elements are reported as analyzed, not on a carbonate-free basis. REE results of six samples are presented in Table 4 . Because of the small numbers of samples examined in this study, only general trends were observed.

Great variability exists in the contents of both major and trace elements in the samples. For example, contents of magnesium (MgO) vary from $1.25 \%$ to $29.95 \%$; calcium (CaO), from $4.57 \%$ to $37.20 \%$; $\mathrm{Cr}$, from 28 to $2460 \mathrm{ppm}$; and nickel (Ni), from 41 to $793 \mathrm{ppm}$. This variability largely reflects changes in sediment mineralogy caused by differences in proportions of igneous and biogenic material. In addition, certain samples have been anomalously enriched in specific elements, for example, lead $(\mathrm{Pb})$ and zinc $(\mathrm{Zn})$ in calcareous ooze Sample AFZ7 are enriched by 8 and 11 times the average of other samples, respectively, and barium $(\mathrm{Ba})$ in calcareous ooze Sample AFZ6 is enriched by 25 times the mean for the remaining samples.

On the basis of comparisons with average oceanic pelagic sediment (Chester and Aston, 1976), Atlantis II Fracture Zone sediments are typically enriched in $\mathrm{MgO}$ and fall into three distinct groupings, as follows:

1. Hole 732B: Sediment samples have silica $\left(\mathrm{SiO}_{2}\right)$ and alumina $\left(\mathrm{Al}_{2} \mathrm{O}_{3}\right)$ comparable to oceanic averages; are enriched in $\mathrm{MgO}$, phosphorous $\left(\mathrm{P}_{2} \mathrm{O}_{5}\right)$, titania $\left(\mathrm{TiO}_{2}\right)$, iron $\left(\mathrm{Fe}_{2} \mathrm{O}\right)$, and $\mathrm{Na}_{2} \mathrm{O}$; and are depleted in manganese $(\mathrm{MnO})$, potassium $\left(\mathrm{K}_{2} \mathrm{O}\right)$, and $\mathrm{CaO}$. Trace elements in these samples are variously enriched $(\mathrm{Cr}, \mathrm{Ni}, \mathrm{V})$, depleted $(\mathrm{Ba}, \mathrm{Pb}, \mathrm{Zn})$ and comparable (strontium $[\mathrm{Sr}], \mathrm{Co}$ ) to average values in deep-sea clays (Fleet and Kempe, 1974).

2. Holes 734B and 734G: Samples have comparable $\mathrm{P}_{2} \mathrm{O}_{5}$ values, are enriched in $\mathrm{Fe}_{2} \mathrm{O}_{3}$, and are depleted in the remaining major elements, compared to average oceanic pelagic sediments. Compared with average trace-element values for deep-sea clays, $\mathrm{Cr}, \mathrm{Ni}, \mathrm{Sr}$, and $\mathrm{Co}$ are enriched and copper $\mathrm{Cu}$ is depleted in these samples. The range in $\mathrm{Ba}, \mathrm{Pb}, \mathrm{V}$, and $\mathrm{Zn}$ contents is large, and values vary from significantly higher to significantly lower than the average for deep-sea clays.

Conrad RC 27-9 calcareous ooze samples have comparable major-element chemistries to average oceanic calcareous pelagic sediments, with the exceptions of $\mathrm{Na}_{2} \mathrm{O}$ and $\mathrm{P}_{2} \mathrm{O}_{5}$, and $\mathrm{K}_{2} \mathrm{O}$ and $\mathrm{MnO}$, which are enriched and depleted, respectively. The majority of trace elements in these two ooze samples are enriched relative to average deep-sea carbonates (Fleet and Kempe, 1974); however, $\mathrm{Sr}$ is depleted and $\mathrm{Pb}$ and $\mathrm{V}$ values are similar. 
Table 3. Major and trace element contents of Atlantis II Fracture Zone sediments.

\begin{tabular}{|c|c|c|c|c|c|c|c|c|c|c|c|c|}
\hline \multirow[b]{2}{*}{ Sample } & \multicolumn{11}{|c|}{ Percentage } & \multirow[b]{2}{*}{ Total } \\
\hline & $\mathrm{SiO}_{2}$ & $\mathrm{Al}_{2} \mathrm{O}_{3}$ & $\mathrm{TiO}_{2}$ & $\mathrm{Fe}_{2} \mathrm{O}_{3}$ & $\mathrm{CaO}$ & $\mathrm{MgO}$ & $\mathrm{K}_{2} \mathrm{O}$ & $\mathrm{Na}_{2} \mathrm{O}$ & $\mathrm{MnO}$ & $\mathrm{P}_{2} \mathrm{O}_{5}$ & LOI & \\
\hline AFZ4 & 45.62 & 11.15 & 1.12 & 9.32 & 6.56 & 11.35 & 0.63 & 2.75 & 0.20 & 0.63 & 8.19 & 97.52 \\
\hline AFZ10 & 46.27 & 13.91 & 1.40 & 9.35 & 7.87 & 11.25 & 0.38 & 2.90 & 0.21 & 0.22 & 5.15 & 98.91 \\
\hline AFZ5 & ${ }^{\mathrm{a}} 44.44$ & 9.35 & 0.91 & 6.71 & 10.93 & 5.63 & 1.12 & 1.75 & 0.27 & 0.21 & ${ }^{\mathrm{a}} 19.38$ & 100.7 \\
\hline AFZ11 & 47.56 & 14.75 & 1.62 & 10.16 & 8.94 & 9.32 & 0.38 & 3.29 & 0.18 & 0.27 & 4.21 & 100.68 \\
\hline AFZ12 & 44.03 & 9.73 & 1.05 & 9.78 & 4.57 & 19.70 & 0.35 & 2.61 & 0.17 & 0.18 & 8.21 & 100.38 \\
\hline $\mathrm{AFZ1}$ & $b_{23.01}$ & 2.01 & 0.08 & 4.10 & 21.77 & 15.50 & 0.06 & 0.37 & 0.14 & 0.14 & $b_{26.95}$ & 94.13 \\
\hline AFZ2 & $b_{34.67}$ & 2.75 & 0.13 & 6.97 & 11.90 & 26.11 & 0.07 & 0.35 & 0.16 & 0.14 & $b_{17.03}$ & 100.28 \\
\hline AFZ13 & 37.05 & 2.79 & 0.18 & 8.01 & 7.95 & 29.95 & 0.07 & 0.36 & 0.11 & 0.15 & 14.82 & 101.44 \\
\hline AFZ6 & a 27.79 & 3.97 & 0.29 & 6.37 & 19.02 & 13.80 & 0.20 & 0.51 & 0.10 & 0.18 & $a_{22.10}$ & 94.33 \\
\hline AFZ7 & $b_{33.19}$ & 3.40 & 0.40 & 8.01 & 14.24 & 20.92 & 0.11 & 0.73 & 0.12 & 0.18 & $b_{17.58}$ & 98.88 \\
\hline AFZ3 & $b_{34.18}$ & 3.38 & 0.42 & 7.34 & 14.45 & 22.44 & 0.10 & 0.56 & 0.13 & 0.18 & $b_{17.72}$ & 100.9 \\
\hline AFZ8 & 28.81 & 5.51 & 0.37 & 3.43 & 32.50 & 1.58 & 0.89 & 1.20 & 0.22 & 0.22 & 27.06 & 103.79 \\
\hline AFZ9 & 22.12 & 4.60 & 0.28 & 2.71 & 37.20 & 1.25 & 0.74 & 1.46 & 0.17 & 0.20 & 32.06 & 102.79 \\
\hline
\end{tabular}

Parts per million

\begin{tabular}{|c|c|c|c|c|c|c|c|c|c|c|c|c|c|}
\hline Sample & $\mathrm{Ba}$ & Co & $\mathrm{Cr}$ & $\mathrm{Cu}$ & $\mathrm{Mn}$ & $\mathrm{Ni}$ & $\mathrm{Pb}$ & $\mathrm{Rb}$ & $\mathrm{Sr}$ & V & $\mathrm{Y}$ & $\mathrm{Zn}$ & $\mathrm{Zr}$ \\
\hline AFZ4 & 95 & 75 & 834 & 103 & 1791 & 463 & 48 & 16 & 122 & 174 & 27 & 293 & 99 \\
\hline AFZ10 & 66 & 69 & 493 & 56 & 1643 & 374 & 15 & 12 & 110 & 178 & 25 & 80 & 100 \\
\hline AFZ5 & 1157 & 51 & 232 & 105 & 1969 & 170 & 28 & $a_{36}$ & 328 & 106 & 23 & 104 & ${ }^{a} 114$ \\
\hline AFZ11 & 78 & 43 & 668 & 61 & 1376 & 258 & 11 & 5 & 137 & 224 & 35 & 95 & 108 \\
\hline AFZ12 & 104 & 76 & 1232 & 74 & 1445 & 782 & 15 & 9 & 90 & 165 & 20 & 93 & 68 \\
\hline AFZ1 & 78 & 78 & 1071 & 69 & 1179 & 892 & 66 & $b_{4}$ & 1433 & 10 & 13 & 232 & ${ }^{b} 93$ \\
\hline AFZ2 & 49 & 108 & 2159 & 66 & 1606 & 1793 & 47 & $b_{8}$ & 1629 & 35 & 15 & 166 & $\mathrm{~b}_{123}$ \\
\hline AFZ13 & 17 & 105 & 2460 & 29 & 1118 & 1533 & 3 & 2 & 965 & 36 & 12 & 51 & 65 \\
\hline AFZ6 & 13122 & 71 & 1012 & 47 & 856 & 702 & 126 & 29 & 683 & 203 & 11 & 246 & ${ }^{a} 80$ \\
\hline AFZ7 & 1325 & 75 & 1566 & 34 & 1117 & 1129 & 311 & $b_{2}$ & 507 & 57 & 14 & 1457 & $b_{50}$ \\
\hline AFZ3 & 1316 & 95 & 1535 & 43 & 1140 & 1270 & 52 & $b_{5}$ & 588 & 57 & 10 & 131 & ${ }^{b} 55$ \\
\hline AFZ8 & 1121 & 28 & 41 & 82 & 1628 & 45 & 22 & 23 & 898 & 38 & 19 & 52 & 84 \\
\hline AFZ9 & 969 & 24 & 28 & 76 & 1294 & 41 & 14 & 21 & 1006 & 19 & 17 & 47 & 80 \\
\hline
\end{tabular}

${ }^{a}$ Based on $<62 \mu \mathrm{m}$ fraction.

${ }^{b}$ Based on $>62 \mu \mathrm{m}$ fraction.

Table 4. REE contents of selected sediments, Atlantis II Fracture Zone.

\begin{tabular}{lcccccc}
\hline $\begin{array}{c}\text { Element } \\
\left(\text { ppm }^{\mathrm{a}}\right)\end{array}$ & $\begin{array}{c}\text { AFZ-1 } \\
\text { mud }\end{array}$ & $\begin{array}{c}\text { AFZ-2 } \\
\text { mud }\end{array}$ & $\begin{array}{c}\text { AFZ-3 } \\
\text { mud }\end{array}$ & $\begin{array}{c}\text { AFZ-7 } \\
\text { mud }\end{array}$ & $\begin{array}{c}\text { AFZ-5 } \\
\text { sand }\end{array}$ & $\begin{array}{c}\text { AFZ-6 } \\
\text { sand }\end{array}$ \\
\hline $\mathrm{La}$ & 4.17 & 2.74 & 4.58 & 4.59 & 5.22 & 2.12 \\
$\mathrm{Ce}$ & 9.18 & 7.50 & 10.4 & 9.49 & 11.7 & 4.97 \\
$\mathrm{Pr}$ & 1.36 & 1.14 & 1.63 & 1.51 & 2.37 & 0.85 \\
$\mathrm{Nd}$ & 5.42 & 5.40 & 6.52 & 6.68 & 11.2 & 3.72 \\
$\mathrm{Sm}$ & 1.16 & 1.34 & 1.43 & 1.48 & 2.62 & 1.07 \\
$\mathrm{Eu}$ & 0.40 & 0.34 & 1.34 & 0.98 & 1.05 & 0.49 \\
$\mathrm{Gd}$ & 1.55 & 1.46 & 1.86 & 1.84 & 3.54 & 1.30 \\
$\mathrm{~Tb}$ & 0.24 & 0.31 & 0.26 & 0.30 & 0.59 & 0.20 \\
$\mathrm{Dy}$ & 1.60 & 2.01 & 2.15 & 2.29 & 4.11 & 1.44 \\
$\mathrm{Ho}$ & 0.38 & 0.42 & 0.44 & 0.48 & 0.82 & 0.30 \\
$\mathrm{Er}$ & 1.09 & 1.25 & 1.25 & 1.29 & 2.54 & 1.16 \\
$\mathrm{Tm}$ & 0.16 & 0.20 & 0.17 & 0.18 & 0.30 & 0.12 \\
$\mathrm{Yb}$ & 0.91 & 1.06 & 1.23 & 1.21 & 2.03 & 0.78 \\
$\mathrm{Lu}$ & 0.14 & 0.15 & 0.19 & 0.18 & 0.30 & 0.09 \\
$\mathrm{La} / \mathrm{Yb}$ & 4.58 & 2.58 & 3.72 & 3.79 & 2.57 & 2.72 \\
$\mathrm{Ce} / \mathrm{La}$ & 2.20 & 2.74 & 2.27 & 2.07 & 2.24 & 2.34 \\
\hline
\end{tabular}

a Size fraction: mud-less than $62 \mu \mathrm{m}$; sand-greater than $62 \mu \mathrm{m}$.

Compared to active ridge sediments (ARS) (Chester and Aston, 1976), $\mathrm{Cr}$ and $\mathrm{Ni}$ are significantly enriched in all sediments of the Atlantis II Fracture Zone samples, while the remaining transition metals are depleted. Exceptions include Samples AFZ2 and AFZ13, where Co values are comparable to ARS compositions, and AFZ7, where $\mathrm{Zn}$ content is significantly higher. $\mathrm{Fe}_{2} \mathrm{O}_{3}$ and $\mathrm{MnO}$ contents typical of metal-rich hydrothermal sediments were not noted in the Atlantis II Fracture Zone samples, indicating that the enrichments of trace elements are the result of factors other than hydrothermal effects.
A number of geochemical studies on sediments from the Indian Ocean have been conducted previously (Bostrom and Fisher, 1971 [Indian Ocean]; Cook, 1974 [eastern Indian Ocean]; Fleet and Kempe, 1974 [southern Indian Ocean]; Pimm, 1974 [Wharton Basin]; McArthur and Elderfield, 1977 [Mid-Indian Ocean Ridge and Marie Celeste Fracture Zone]). A single sample from the floor of the Marie Celeste Fracture Zone provides the closest comparison by tectonic setting. This sample contains significantly more $\mathrm{CaCO}_{3}$ and less $\mathrm{SiO}_{2}$, $\mathrm{Fe}_{2} \mathrm{O}_{3}, \mathrm{MnO}, \mathrm{K}_{2} \mathrm{O}, \mathrm{P}_{2} \mathrm{O}_{5}$, and $\mathrm{MgO}$ than the Atlantis II Fracture Zone sediments. $\mathrm{TiO}_{2}$ and $\mathrm{Al}_{2} \mathrm{O}_{3}$ values are comparable to contents in sediments from Holes $734 \mathrm{~B}$ and $734 \mathrm{G}$, and Conrad RC 27-9, while $\mathrm{Na}_{2} \mathrm{O}$ is enriched. Compared with sediment analyses in other Indian Ocean localities, the Atlantis II Fracture Zone sediments are generally uniformly enriched in $\mathrm{MgO}, \mathrm{TiO}_{2}, \mathrm{Cr}$, and $\mathrm{Ni}$, while the patterns for other elements are more variable, depending on sediment lithology.

Major and trace element contents of $<62$ - and $>62-\mu \mathrm{m}$ splits of selected samples are shown in Table 5 . The $<62-\mu \mathrm{m}$ portions of the samples generally contain higher proportions of $\mathrm{Ba}, \mathrm{Cu}$, $\mathrm{Pb}, \mathrm{Sr}, \mathrm{V}, \mathrm{Zn}, \mathrm{TiO}_{2}$, and $\mathrm{CaO}$ than do the sand-sized fractions of the same samples, although there are some reversals of this relationship. This reflects a size fractionation to higher concentrations of carbonate and accessory titanium oxides in the silt and clay fractions. Although deep-sea carbonates and other ooze sediments are generally depleted in most trace elements relative to average deep-sea clays, it has been shown that high levels of $\mathrm{Zn}, \mathrm{Pb}, \mathrm{V}$, and $\mathrm{Sr}$ may be found in calcareous tests (Chester and Aston, 1976), possibly associated with iron hydroxide coatings on the test surfaces. In addition, Dymond et al. (1980) showed that high percentages of $\mathrm{Cu}, \mathrm{Zn}$, and $\mathrm{Mn}$ in Galapagos carbonates were leachable with hydrochloride acetic acid. Elements 
such as $\mathrm{Sr}, \mathrm{Pb}, \mathrm{Zn}$, and possibly $\mathrm{V}$ in the Atlantis II Fracture Zone sediments thus may represent (at least in part) a biogenic contribution. The sand fraction of the split samples tends to contain significantly higher $\mathrm{Co}, \mathrm{Cr}, \mathrm{Ni}, \mathrm{Fe}_{2} \mathrm{O}_{3}$, and $\mathrm{MgO}$ than the mud portion, reflecting a greater proportion of lithogenous or basement-derived clastic material. This, therefore, indicates a partitioning of elements in the sediments by texture and associated composition.

\section{Source Provinces and Lithology}

One of the most important controls on the geochemistry and mineralogy of sediments in the Atlantis II Fracture Zone is sediment source and the resultant sediment lithology. All sediment samples examined in this study have higher $\mathrm{MgO}$, $\mathrm{Cr}$, and $\mathrm{Ni}$ contents than average pelagic sediments and other Indian Ocean sediments. The levels of these elements are in the ranges documented for ultramafic lithologies (Engel and Fisher, 1975). The sediments accumulating in this fracture zone thus are thought to reflect significant contributions from ultramafic source rocks. A local source for much of this material is supported by the thin nature of the sedimentary sequence in most parts of the fracture-zone environment, the serpentinitic and ultramafic composition, and the rubbly, coarse, proximal nature of most of the basal sediments, in addition to the common exposure of the serpentinitized peridotite. Sediment samples from Holes 734B and 734G, because of their high $\mathrm{MgO}$ (13.8\% to $29.95 \%), \mathrm{Cr}, \mathrm{Ni}$, and Co contents; low $\mathrm{Al}_{2} \mathrm{O}_{3}, \mathrm{~K}_{2} \mathrm{O}, \mathrm{Na}_{2} \mathrm{O}$, and rubidium ( $\mathrm{Rb}$ ) contents; and characteristic serpentine, brucite, and magnetite mineral assemblages, reflect the highest contribution from this source. The second identifiable source is basalt, which distinguishes Hole 732B sediment samples from the above-mentioned primarily serpentinite-derived samples. Hole 732B samples are characterized by high $\mathrm{SiO}_{2}, \mathrm{Al}_{2} \mathrm{O}_{3}, \mathrm{TiO}_{2}, \mathrm{Fe}_{2} \mathrm{O}_{3}, \mathrm{Na}_{2} \mathrm{O}$, V, Y (scattered $\mathrm{Cu}$ ), and low $\mathrm{Sr}$. Characteristic minerals include amphibole, and clinopyroxene, and albite, analcime and smectite, which are, respectively, typical mafic minerals and their submarine weathering products. These samples thus are influenced by basaltic and subsidiary serpentinitic sources, as is suggested by the nature of clasts in the basal sediments of Core 118-732B-1H (dominated by basalt and diabase at Site 732 , and specifically phyric basalt at the $135-150 \mathrm{~cm}$ interval, and weathered basalt and serpentinite at the $70-95 \mathrm{~cm}$ inter$\mathrm{val}$ ). The third sediment source is calcareous ooze (in particparticular, foraminiferal ooze) and diatoms and sponges. Samples that contain a high proportion of calcareous ooze (particularly samples from RC 27-9) exhibit high $\mathrm{CaO}$ and $\mathrm{Sr}$, and low $\mathrm{SiO}_{2}, \mathrm{TiO}_{2}, \mathrm{Fe}_{2} \mathrm{O}_{3}$, and $\mathrm{Cr}$. As suggested by results of the sample splits, a high proportion of $\mathrm{Pb}$ and $\mathrm{Zn}$ may also be contributed through the biogenic components. Major mineral phases in these samples are calcite and quartz. In addition, these phases contain traces of kaolinite and illite not observed in other Atlantis II Fracture Zone sediments.

Proportions of the three source materials in the sediments may reflect (1) the thickness of the sediment cover (thin sedimentary sections, for example, less than $2 \mathrm{~m}$, appear to have higher contents of basement-derived material in the sediment, while in thicker sediment ponds ooze material appears to dominate, and long-distance transported clay minerals are more likely to be present), and (2) the nature of the basement, i.e., serpentinite, gabbro, peridotite, or basalt. Thickness of the sediment cover is probably related to average seafloor slope, with greatest thicknesses occurring on lower slopes. Higher slope areas with thinner sediment cover may also be more proximal to basement outcrops. The distinction between the three source provinces is illustrated using a ternary diagram showing $\mathrm{CaO}, \mathrm{Al}_{2} \mathrm{O}_{3}$, and $\mathrm{MgO}$ (Fig. 1). $\mathrm{A}$ certain amount of overlap may occur, where, for example, a calcareous ooze sample like AFZ1 also includes a significant proportion of ultramafic material.

Table 5. Major and trace element contents of $<62 \mu \mathrm{m}$ and $>62 \mu \mathrm{m}$ splits of selected sediments.

\begin{tabular}{|c|c|c|c|c|c|c|c|c|c|c|c|c|c|}
\hline \multirow[b]{2}{*}{ Sample } & \multicolumn{10}{|c|}{ Percentage } & & & \\
\hline & $\mathrm{SiO}_{2}$ & $\mathrm{Al}_{2} \mathrm{O}_{3}$ & $\mathrm{TiO}_{2}$ & $\mathrm{Fe}_{2} \mathrm{O}_{3}$ & $\mathrm{CaO}$ & $\mathrm{MgO}$ & $\mathrm{K}_{2} \mathrm{O}$ & $\mathrm{Na}_{2} \mathrm{O}$ & $\mathrm{MnO}$ & $\mathrm{P}_{2} \mathrm{O}_{5}$ & & & \\
\hline AFZ5 & 44.44 & 9.01 & 0.87 & 6.66 & 13.00 & 3.45 & 1.40 & 1.48 & 0.32 & 0.25 & & & \\
\hline AFZ5S & & 10.20 & 1.00 & 6.81 & 5.60 & 11.26 & 0.40 & 2.44 & 0.14 & 0.09 & & & \\
\hline $\mathrm{AFZ1}$ & & 2.10 & 0.12 & 2.59 & 25.68 & 9.75 & 0.07 & 0.89 & 0.15 & 0.07 & & & \\
\hline AFZIS & 23.01 & 2.01 & 0.06 & 4.51 & 20.73 & 17.02 & 0.06 & 0.23 & 0.14 & 0.16 & & & \\
\hline AFZ2 & & 3.29 & 0.17 & 4.43 & 12.67 & 18.49 & 0.01 & 1.11 & 0.13 & 0.05 & & & \\
\hline AFZ2S & 34.67 & 2.71 & 0.13 & 7.16 & 11.84 & 26.69 & 0.07 & 0.29 & 0.16 & 0.15 & & & \\
\hline AFZ6 & 27.79 & 4.09 & 0.31 & 6.56 & 19.64 & 13.27 & 0.24 & 0.53 & 0.10 & 0.21 & & & \\
\hline AFZ6S & & 3.06 & 0.18 & 4.98 & 14.49 & 17.66 & 0.01 & 0.31 & 0.12 & 0.02 & & & \\
\hline AFZ7 & & 3.25 & 0.40 & 5.55 & 17.01 & 12.06 & 0.06 & 0.50 & 0.10 & 0.09 & & & \\
\hline AFZ7S & 33.19 & 3.42 & 0.41 & 8.32 & 13.90 & 22.01 & 0.12 & 0.75 & 0.12 & 0.19 & & & \\
\hline AFZ3 & & 3.19 & 1.00 & 4.99 & 16.73 & 11.86 & 0.10 & 0.78 & 0.09 & 0.07 & & & \\
\hline \multirow[t]{2}{*}{ AFZ3S } & 34.18 & 3.40 & 0.35 & 7.63 & 14.17 & 23.75 & 0.10 & 0.53 & 0.13 & 0.19 & & & \\
\hline & \multicolumn{13}{|c|}{ Parts per million } \\
\hline Sample & $\mathrm{Ba}$ & Co & $\mathrm{Cr}$ & $\mathrm{Cu}$ & $\mathrm{Mn}$ & $\mathrm{Ni}$ & $\mathrm{Pb}$ & $\mathrm{Rb}$ & $\mathrm{Sr}$ & V & $\mathrm{Y}$ & $\mathrm{Zn}$ & $\mathrm{Zr}$ \\
\hline AFZ5 & 1587 & 55 & 140 & 102 & 2296 & 116 & 32 & 36 & 412 & 93 & 25 & 107 & 114 \\
\hline AFZ5S & 50 & 41 & 470 & 114 & 1130 & 308 & 18 & & 110 & 140 & 18 & 98 & \\
\hline AFZ1 & 150 & 51 & 679 & 103 & 1155 & 477 & 180 & & 1295 & 27 & 7 & 408 & \\
\hline AFZ1S & 59 & 85 & 1175 & 60 & 1185 & 1002 & 36 & 4 & 1470 & 6 & 14 & 185 & 93 \\
\hline AFZ2 & 50 & 75 & 1280 & 84 & 1020 & 875 & 110 & & 1765 & 40 & 9 & 208 & \\
\hline AFZ2S & 49 & 110 & 2225 & 65 & 1650 & 1862 & 42 & 8 & 1619 & 35 & 15 & 163 & 123 \\
\hline AFZ6 & 14870 & 70 & 1016 & 48 & 849 & 695 & 97 & 9 & 715 & 224 & 12 & 238 & 80 \\
\hline AFZ6S & 300 & 78 & 985 & 36 & 905 & 752 & 338 & & 449 & 50 & 7 & 308 & \\
\hline AFZ7 & 6420 & 56 & 739 & 94 & 795 & 516 & 666 & & 763 & 64 & 10 & 1510 & \\
\hline AFZ7S & 695 & 77 & 1668 & 27 & 1157 & 1205 & 267 & 2 & 475 & 56 & 14 & 1450 & 50 \\
\hline AFZ3 & 6610 & 51 & 715 & 70 & 740 & 514 & 116 & & 848 & 61 & 10 & 250 & \\
\hline AFZ3S & 662 & 101 & 1636 & 40 & 1189 & 1363 & 44 & 5 & 556 & 56 & 10 & 116 & 55 \\
\hline
\end{tabular}

AFZ5 $=$ less than $62 \mu \mathrm{m}$ fraction; AFZSS $=$ greater than $62 \mu \mathrm{m}$ fraction. 


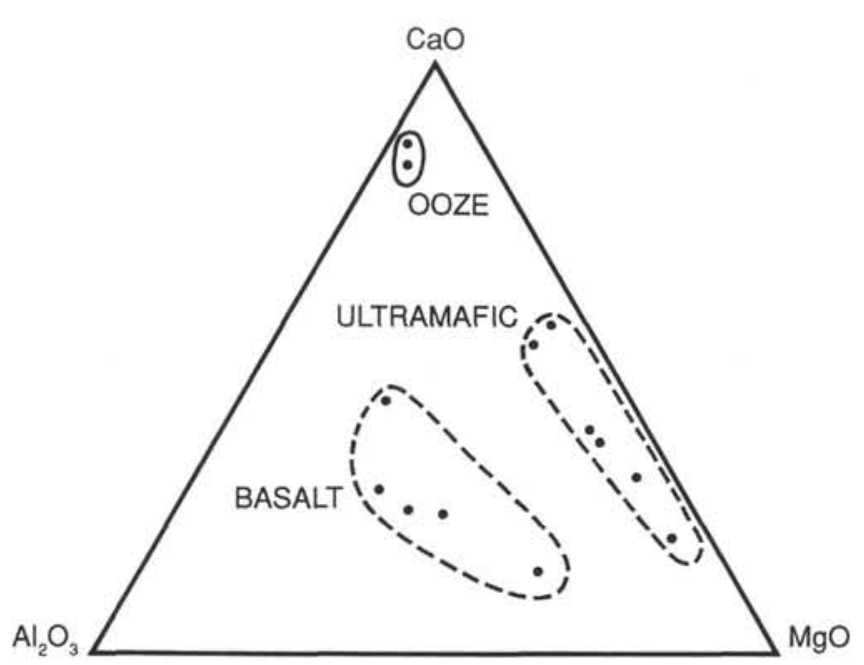

Figure 1. $\mathrm{CaO}, \mathrm{Al}_{2} \mathrm{O}_{3}$, and $\mathrm{MgO}$ ternary diagram showing the separation of ooze, primarily ultramafic-derived, and primarily basaltderived sediments.

\section{Rare Earth Elements}

Compared to a variety of normal deep-sea sediments (for example, Shimokawa et al., 1972; Piper, 1974a, 1974b) and sediments from active plate boundaries (Dymond et al., 1980; Ruhlin and Owen, 1986; Kunzendorf et al., 1988), the REE contents of the Atlantis II Fracture Zone sediments are low. This is most evident for lanthanum ( $\mathrm{La})$, neodymium $(\mathrm{Nd})$, samarium $(\mathrm{Sm})$, terbium $(\mathrm{Tb})$, and lutetium $(\mathrm{Lu})$, while levels of cerium (Ce), europium (Eu), and ytterbium ( $\mathrm{Yb}$ ) are more comparable to average values for sediments from active plate boundaries. Compared with sediments from the Carlsberg and Central Indian Ocean ridges (Kunzendorf et al., 1988), La, Ce, $\mathrm{Nd}$, and $\mathrm{Sm}$ contents are low, $\mathrm{Tb}$ contents are slightly lower, while $\mathrm{Eu}, \mathrm{Yb}$, and $\mathrm{Lu}$ contents are comparable. Ratios of $\mathrm{La}$ to $\mathrm{Yb}$ (degree of fractionation) and $\mathrm{Ce}$ to $\mathrm{La}$ (redox variation)

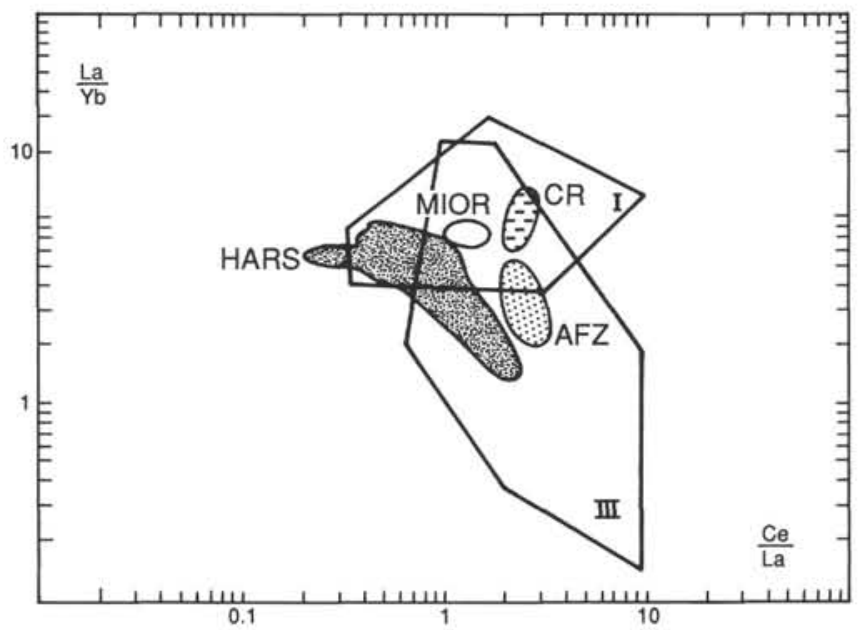

Figure 2. Values of rare earth elements for Atlantis II Fracture Zone sediments plotted onto the characterization scheme of Kunzendorf et al. (1988). HARS = hydrothermally affected ridge sediments, MIOR $=$ Central Indian Ocean Ridge sediments, $\mathrm{CR}=$ Carlsberg Ridge sediments, AFZ = Atlantis II Fracture Zone sediments, Area I = deep-sea sediments, Area $\mathrm{III}=$ marine basalts and related rocks.
(Kunzendorf et al., 1988) for the Atlantis II Fracture Zone sediments plot in the lower right portion of the sedimentary field and in the basalt field (Fig. 2), indicating (1) no evidence of hydrothermal activity (Marchig et al., 1982; Kunzendorf et al., 1988) in these sediments and (2) the presence of abundant relatively unfractionated basaltic and other basement material, particularly in the coarser-grained sediment fractions examined.

\section{CONCLUSIONS}

The sediments from sites drilled in the Atlantis II Fracture Zone exhibit geochemical characteristics, including high $\mathrm{MgO}, \mathrm{Cr}$, and $\mathrm{Ni}$ contents, which readily distinguish them from other deep-sea sediments. Abundant serpentine and the presence of brucite and magnetite, coupled with highest $\mathrm{MgO}, \mathrm{Cr}$, and $\mathrm{Ni}$ contents in samples from Holes $734 \mathrm{~B}$ and $734 \mathrm{G}$ indicate that significant components of these sediments are derived from the ultramafic basement. Site 732 sediments exhibit volumetrically important contributions from basaltic as well as serpentinitic basement materials, as evidenced by the presence of albite, analcime, primary mafic minerals, smectite-chlorite, and high $\mathrm{SiO}_{2}$, $\mathrm{Al}_{2} \mathrm{O}_{3}, \mathrm{TiO}_{2}, \mathrm{Fe}_{2} \mathrm{O}_{3}, \mathrm{~V}$, and $\mathrm{Y}$. A third component of the sediments is the biogenic material, reflected primarily in the presence of carbonates, high $\mathrm{CaO}, \mathrm{Sr}$, and $\mathrm{Pb}$, and $\mathrm{Zn}$ in certain samples.

REE values and ratios of $\mathrm{La}$ to $\mathrm{Yb}$, and $\mathrm{Ce}$ to $\mathrm{La}$ indicate no evidence of hydrothermal activity. This is supported by the major- and trace-element data.

\section{REFERENCES}

Bostrom, K., and Fisher, D. E., 1971. Volcanogenic uranium, vanadium and iron in Indian Ocean sediments. Earth Planet. Sci. Lett., 11:95-98.

Chester, R., and Aston, S. R., 1976. The geochemistry of deep-sea sediments. In Riley, J. P., and Chester, R. (Eds.), Chem. Oceanogr., 6: London (Academic), 281-390.

Cook, P. J., 1974. Major and trace element geochemistry of sediments from Deep Sea Drilling Project, Leg 27, Sites 259-263, eastern Indian Ocean. In Veevers, J. J., Heirtzler, J. R., et al., Init. Repts. DSDP, 27: Washington (U.S. Govt. Printing office), 481-497.

Dymond, J., Corliss, J. B., Cobler, R., Muratli, C. M., Chou, C., and Conard, R., 1980. Composition and origin of sediments recovered by deep drilling of sediment mounds, Galapagos Spreading Center: DSDP Leg 54. In Rosendahl, B. R., Hekinian, R., et al., Init. Repts. DSDP, 54: Washington (U.S. Govt. Printing Office), $377-$ 385.

Engel, C. G., and Fisher, R. L., 1975. Granitic to ultramafic complexes of the Indian Ocean ridge system, western Indian Ocean. Geol. Soc. Am. Bull., 86:1553-1578.

Fisher, R. L., and Sclater, J. G., 1983. Tectonic evolution of the southwest Indian Ocean since the mid-Cretaceous: plate motions and stability of the pole of Antartctica/Africa for at least $80 \mathrm{Myr}$. Geophys. J. R. Astron. Soc., 73:553-576.

Fleet, A. J., and Kempe, D.R.C., 1974. Preliminary geochemical studies of the sediments from DSDP Leg 26, southern Indian Ocean. In Davies, T. A., Luyendyk, B. P., et al., Init. Repts. DSDP, 27: Washington (U.S. Govt. Printing Office), 541-551.

Kolla, V., Bé, A.W.H., and Biscaye, P. E., 1976. Calcium carbonate distribution in the surface sediments of the Indian Ocean. $J$. Geophys. Res., 81:2605-2616.

Kunzendorf, H., Stoffers, P., and Gwozdz, R., 1988. Regional variations of REE patterns in sediments from active plate boundaries. Mar. Geol., 84:191-199.

Marchig, V., Gundlach, H., Moller, P., and Schley, F., 1982. Some geochemical indicators for discrimination between diagenetic and hydrothermal metalliferous sediments. Mar. Geol., 50:241-256.

McArthur, J. M., and Elderfield, H., 1977. Metal accumulation rates in sediments from Mid-Indian Ocean Ridge and Marie Celeste Fracture Zone. Nature, 266:437-439. 
Pimm, A. C., 1974. Mineralisation and trace element variation in deep-sea pelagic sediments of the Wharton Basin, Indian Ocean. In Von der Borch, C. C., Sclater, J. G., et al., Init. Repts. DSDP, 22: Washington (U.S. Govt. Printing Office), 469-476.

Piper, D. Z., 1974a. Rare earth elements in the sedimentary cycle: a summary. Chem. Geol., 14:285-304.

1974b. Rare earth elements in ferromanganese nodules and other marine phases. Geochim. Cosmochim. Acta, 38:10071022.

Rateev, M. A., Gorbunova, Z. N., Lisitzin, A. P., and Nosov, G. L., 1969. The distribution of clay minerals in the ocean. Sedimentology, 13:21-43.

Robinson, P. T., Von Herzen, R. P., et al., 1989. Proc. ODP, Init. Repts., 118: College Station, TX (Ocean Drilling Program).

Ruhlin, D. E., and Owen, R. M., 1986. The rare earth element geochemistry of hydrothermal sediments from the east Pacific Rise: Examination of a seawater scavenging mechanism. Geochim. Cosmochim. Acta, 50:393-400.
Shimokawa, T., Masuda, A., and Izawa, K., 1972. Rare-earth elements in the top samples of cores from the Pacific Ocean floor. Geochem. J., 6:75-81.

Venkatarathnam, Kolla, Henderson, L., and Biscaye, P. E., 1976. Clay mineralogy and sedimentation in the western Indian Ocean. Deep-Sea Res., 23:949-961.

Venkatarathnam, Kolla, and Biscaye, P. E., 1977. Distribution and origin of quartz in the sediments of the Indian Ocean. J. Sediment. Petrol., 47:642-649.

Warren, B. A., 1978. Bottom water transport through the Southwest Indian Ridge. Deep-Sea Res., 25:315-321.

Date of initial receipt: 24 August 1989

Date of acceptance: 17 April 1990

Ms 118B-164 